\title{
Development of Maritime English Learning Construct in Navigation Functions at Politeknik Ilmu Pelayaran Makassar
}

\author{
Ahmad Fauzi ${ }^{1}$, Sukirno ${ }^{1}$, Raphael Baumler ${ }^{2}$ \\ ${ }^{1}$ Politeknik Ilmu Pelayaran Makassar \\ ${ }^{2}$ World Maritime University, WMU - Sweden \\ Jl. Tentara Pelajar No. 173 Makassar \\ e-mail:ahmadfauzi_af@yahoo.com
}

\begin{abstract}
Development of Maritime English Learning Construct in Navigation Function of Politeknik Ilmu Pelayaran. Learning in Politeknik Ilmu Pelayaran must be able to adapt to the latest needs in preparing graduates to have knowledge, understanding and skills of Maritime English in navigation functions so that they meet the minimum requirements as a commercial shipping officer as stipulated in STCW. This study aims to determine how the construct of Maritime English learning in navigation functions with a model developed at Politeknik ilmu Pelayaran. The study was conducted with a model development approach and questionnaires were used to collect data. The research sample were student officers of the Diklat Pelaut I, Politeknik Ilmu Pelayaran. The sampling technique used is proportional random sampling. The data were analyzed by qualitative and quantitative method.
\end{abstract}

Keywords: Learning Construct, Maritime English, Navigation Function, Shipping Competence.

\section{Introduction}

The development of learning constructs has become a topic that has always been discussed in the last decade. The development of learning constructs is based on the development of science and technology that has brought changes in almost all disciplines of science, including education in Maritime English learning in the navigation function of Politeknik Ilmu Pelayaran.

Learning Maritime English in the navigation function is not just an activity to understand a certain concept but how to interpret and apply the concept into a form of competence so that it can be used in real life in this context of merchant shipping. Through learning there will be changes in a person caused by experience. Learning constructivism model according to Karli and Margaretha (2002) is a learning process that begins with cognitive conflict, which in the end knowledge will be built by students through experience and the results of interactions with their environment [5].

Based on these definitions, it is concluded that constructivism learning is generative learning, namely the act of creating something meaningful from what is learned. Constructivism is actually not a new idea, what has been through in our lives so far is the accumulation and formation of experience after experience. This causes a person to have knowledge and become more dynamic. Constructivism involves student officers to actively develop their own knowledge by using previously owned knowledge. Student officers at Politeknik Ilmu Pelayaran are student officers who have sailing experience, so 
they can nurture themselves actively, using the knowledge that student officers have when working as officers on commercial shipping.

A good, creative and dynamic learning process has a significant effect on the achievement of learning objectives. A good process will be able to facilitate the achievement of learning objectives. Good and effective learning is learning that is effective, interactive, creative, educational and fun. To realize good and effective learning, an appropriate learning model is needed. The learning model contains a series of activities that can be used as guidelines so that competence as a learning objective in seafarer education can be achieved optimally. A good learning model in seafarer education clearly states the duties and functions, how to carry out and where the learning activities take place.

Apart from having competence in the field of commercial shipping, the shipping industry currently also requires seafarers who have generic skills (employability skills). Higher order thinking skills such as decision making and problem solving, flexibility, creative thinking, the ability to manage conflict, manage information and resources, and the capacity for reflection.

This phenomenon has become a trend among shipping companies when recruiting seafarers who will sail their company's ships. Shipping companies not only require seafarers to have specific competencies or skills according to the type of ship, the specifications of the ship, and the route of the voyagers to be traversed, but also require that seafarers have non-technical skills such as personal skills, team working, employability skills etc. It is hoped that the Politeknik Ilmu Pelayaran as the provider of Seafarers' Education is expected to equip its graduates with various skills that are suitable to work as professionals in commercial shipping, so that after graduating they can immediately return to work as commercial shipping officers with better competencies. One important aspect of Seafarer Education is the learning process. This is important for Politeknik Ilmu Pelayaran as the delivery of vocational higher education because the nature of education in Politeknik Ilmu Pelayaran is designed to equip graduates with certain applied skills.

The education system is a strategy or method used in the teaching and learning process to achieve goals so that students can actively develop their potential. These components have specific functions that carry out a structural function to achieve the system's goals. The learning system in the Politeknik Ilmu Pelayaran needs to be developed in three aspects, namely: so that student officers understand and master their areas of expertise (know-what), so that student officers understand how a job is done (know-how), so that student officers have an understanding of why a job is done. done (know-why). The education system is essentially a set of means obtained to cultivate the cultural values of the community which can undergo changes in form and model according to the demands of the people's life needs in order to pursue the ideals of a physically and mentally prosperous life [1].

Currently, the learning approach to vocational education leads to: (1) learner-centered learning, (2) work-centered learning, and (3) learning that focuses on developing attributes. attribute-focused skills [3]. The learner-centered approach assumes that student officers play an active role and have unlimited potential to be developed, knowledge construction is carried out together, and learning objectives are achieved through involvement in various activities.

Learner-centered is a learning principle that emphasizes active and reflective learners, not teachers. In fact, education will be better if the main focus is on people 
learning. Problem-based learning is a learning model that directly presents examples of real case problems that often appear daily in the learning itself. In the Bandura learning model, the person (cognitive) factor plays an important role. The person (cognitive) factor currently referred to is self-efficacy or self-efficacy. Self-efficacy is the belief in one's own ability to organize and mobilize the sources of action needed to manage future situations, Bandura argues that when individuals become more aware of what is 'going on' (realizing what can function as reinforcing events ) then the person is increasingly skilled at using his ability to realize what needs to be done (Neil, 2004).

The level of self-efficacy varies from one individual to another. If a person has a high level of efficacy, he is always sure of his ability to do something, while someone who has a low level of self-efficacy will always hesitate and half-heart in completing his task. Self-efficacy also means believing yourself to be successful and successful [9]. Based on the description above, it is necessary to develop a learning model in the perspective of the Maritime English learning construct in the navigation function of seafarer education.

\section{Research Method}

The type of research in this study is R and D (Research and Development) using a development model developed by Borg \& Gall. This means that the stages in this research follow the research and development steps developed by Borg and Gall. This type of research is in line with the main objective of this study, which is to produce a Maritime English learning model in the navigation function to improve the competence of student officers in Maritime English. Research and development is a research process used to develop and validate educational products [2]. The term product is not only in the form of material objectives, such as textbooks, learning films, and the like; but also concerning matters that aim to establish processes and procedures, such as: learning methods, methods of organizing learning, or learning models. The purpose of development research is not only to develop products, but rather to discover new knowledge through basic research or answer specific questions about practical problems through applied research.

Borg and Gall (2003) suggest the procedure for implementing model development research that follows the development research cycle, namely: (1) initial research and information collection (research and information collecting), (2) planning, (3) preparation of the initial model format. (develop preliminary form of product), (4) preliminary field testing, (5) revision of the main model (main product revision), (6) field test of the main model (main field testing), (7) revision operational model (operational product revision), (8) operational field testing, (9) final product revision, and (10) dissemination and distribution [2].

\section{Definition of Terms}

This study uses three terms used to measure the development of the developed learning model. To maintain consistency in the interpretation of these terms, the following is an explanation and interpretation of each of these terms.

1. Validity

In this study, the term validity is a criterion to measure the validity of the Teaching Implementation Plan, Student Officer Worksheets, Teaching Materials, and Model Implementation Manuals seen from the point of content validity and appearance validity. 2. Practicality

In this study, the term practicality is a criterion for measuring the feasibility of a developed model which includes (1) syntax, (2) social systems, (3) reaction principles (4) support 
systems, and (5) instructional and accompaniment impacts. The model book consists of the Teaching Implementation Plan, Student Officer Worksheets, Teaching Materials, and Model Implementation Manual.

3. Effectiveness

In this study, the term effectiveness is a criterion for measuring the effectiveness of a model developed by paying attention to four main components, namely (1) student officer responses, (2) learning activities, and (3) learning management.

\section{Data Analysis Technique}

The data that has been obtained through the above activities are then analyzed qualitatively and quantitatively. The analysis was carried out to answer the research question, namely: whether the Maritime English learning model in the navigation function of the seafarer education program can be declared valid, practical and effective.

\subsection{Analysis of the Validity of the Learning Model}

Validation was carried out through an assessment of the model developed (instrument 1). The validity category of each aspect of all assessed aspects is determined based on the criteria for categorizing the quality of the equipment adapted from the categorization according to Azwar (2010), as shown in table 1 below.

Table 1. Category of Instrument Validity

\begin{tabular}{|c|l|}
\hline Score Range & \multicolumn{1}{|c|}{ Category } \\
\hline$<\mathrm{M}<5,0$ & Very valid \\
\hline$<\mathrm{M}<4,5$ & Valid \\
\hline$<\mathrm{M}<3,5$ & Quite valid \\
\hline$<\mathrm{M}<2,5$ & Less valid \\
\hline$<\mathrm{M}<1,5$ & Invalid \\
\hline
\end{tabular}

$\mathrm{M}=$ mean value for each aspect assessed.

The criterion used to decide that the instrument has an adequate degree of validity is if the $\mathrm{M}$ mean of the assessment results for all minimal aspects is in the valid category. If it is invalid, then a revision will be made based on the suggestions of the validators or by looking back at the aspects that are lacking. Furthermore, it is re-validated and then analyzed again. And so on until it meets the minimum average value in the valid category.

\subsection{Data Analysis}

The practicality data of the learning model is seen from the results of the analysis of the assessment data on the observations of the model's implementation (instrument 2) in the Maritime English learning process in the navigation function. Practical data analysis was carried out through data processing from observations of the implementation of Maritime English learning in the navigation function.

Data analysis was carried out to observe the feasibility of learning from each aspect of the model components. The observed value was analyzed by determining the average value of the implementation of $\mathrm{T}$. The $\mathrm{T}$ value was further confirmed by the interval determination of the model implementation category in table 2 . below. 
Table 2. Model Implementation Category

\begin{tabular}{|c|l|}
\hline Average Score & \multicolumn{1}{|c|}{ Category } \\
\hline $4,5<\mathrm{T} \leq 5$ & Fully implemented \\
\hline $3,5<\mathrm{T} \leq 4,5$ & Almost entirely implemented \\
\hline $2,5<\mathrm{T} \leq 3,5$ & Mostly implemented \\
\hline $1,5<\mathrm{T} \leq 2,5$ & Few implemented \\
\hline $\mathrm{T} \leq 1,5$ & Not implemented \\
\hline
\end{tabular}

$\mathrm{T}=$ the model's implementation

To decide that the learning model is implemented, the minimum $\mathrm{T}$ value is in the mostly implemented category. If the $\mathrm{T}$ value is in the category of a small part is implemented or not implemented, then a revision is made to the model until the model is in the category of mostly implemented or entirely implemented.

1. Analysis of Learning Model Effectiveness Data

The analysis was carried out on the two components of the model's effectiveness, namely: (1) student officer learning outcomes (instrument 3) and (instrument 4) student officer responses through questionnaires (instrument 5).

2. Data Analysis of Student Officer Learning Outcomes

Data on the effectiveness of student officer learning outcomes in Maritime English learning in the navigation function can be seen from three aspects, namely: (1) normalized gain average (2) Minimum completeness criteria (KKM), and (3) classical completeness. Analysis of normalized gain average results before and after learning with Maritime English in the navigation function is processed to determine the increase in student officer learning outcomes. The amount of increase before and after learning was calculated using the Wilcoxon Signed Rank Test. Ghozali (2002) explains that the Wilcoxon Signed Rank Test is a nonparametric test to measure the significance of the difference between 2 groups of paired data with ordinal or interval scales but with an abnormal distribution. The Wilcoxon Signed Rank Test is an alternative test of the paired t test or paired $t$ if it does not meet the assumption of normality. The Wilcoxon Signed Rank Test is used to measure the significance of differences in student test scores before and after learning English in the navigation function with the model developed [4].

Through this test it is known that there are 2 variables, including: 1 independent variable, namely learning with 2 groups (before learning and after learning), 1 dependent variable, namely the value of learning outcomes. The before and after groups are groups that are paired because the sample or subject is the same individual or observation. Each sample is that each student officer has 2 attributes, namely the test score before class and the test score after learning Maritime English in the navigation function.

Data on the average value of learning outcomes were analyzed using descriptive statistics. Student officers 'learning outcomes data were analyzed quantitatively by using descriptive statistics with the aim of describing the characteristics of student officers' learning outcomes. The distribution of values is presented in the form of a frequency distribution after being converted to a scale of five with categories, namely: mastery level 80-100 is categorized as very good, 70-79 is categorized as good, 60-69 is categorized as sufficient, 50-59 is categorized as poor, and 0-49 is categorized as bad. The categories of learning outcomes can be seen in table 3. below. 
Table 3. Category of Student Officer Learning Outcomes

\begin{tabular}{|c|l|}
\hline Interval Value & \multicolumn{1}{|c|}{ Category } \\
\hline $80-100$ & $\mathrm{~A}=$ Distinction \\
\hline $70-79$ & $\mathrm{~B}=$ Excellent \\
\hline $60-69$ & $\mathrm{C}=$ Good \\
\hline $50-59$ & $\mathrm{D}=$ Pass \\
\hline $0-59$ & $\mathrm{E}=$ Failure \\
\hline
\end{tabular}

The minimum completeness criteria $(\mathrm{KKM})$ in the seafarer education program is a minimum of 70, namely the minimum value specified in the QSS (Quality Standard System) in the Guidelines for the Implementation of Maritime Education No. 2162 of 2010. Based on these criteria, student officers who get $N \geq 70$ are declared to have achieved completeness of learning outcomes, while classical completeness is determined by the number of student officers who get a minimum score of 70 . Student officer learning outcomes are said to be effective if classical completeness is achieved, namely at least $85 \%$ student officers achieve a minimum score of 70 .

\subsection{Analysis of Student Officer Responses}

Student officers' responses were obtained from the results of questionnaires to student officers after the learning ended. Data analysis of student officers' responses to English in the navigation function with the developed model. The category of student officer response aspects is determined based on the criteria in Table 4. as follows:

Table 4. Student Officer Responses

\begin{tabular}{|c|l|}
\hline Average & \multicolumn{1}{|c|}{ Category } \\
\hline 5,0 & Very positive \\
\hline 4,0 & Positive \\
\hline 3,0 & Tend to be positive \\
\hline 2,0 & Tend to be negative \\
\hline 1,0 & Negative \\
\hline
\end{tabular}

The response of student officers to learning English in the navigation function with the model developed is categorized as effective if there are more than $70 \%$ of student officers who respond with a minimal category that tends to be positive. If the response of student officers tends to be negative, greater than $30 \%$, it is necessary to revise the learning device. Furthermore, it was re-analyzed until it reached more than $70 \%$ of student officers giving responses with a minimal category tending to be positive.

\section{Research Results}

\subsection{Validity}

Osborne and Cosgrove's Generative Theory as in Sutarman and Swasono (2003) states that generative learning is a learning model that emphasizes actively integrating new knowledge using previously owned knowledge. In relation to student officers who participate in the seafaring education program, all of them are student officers who already 
have knowledge and experience, especially those related to ship maneuvers and shipping communications using Maritime English in navigation functions. The results of the analysis of the mean value obtained from each of the assessed components obtained an average value that met the requirements to state that the learning device was declared a very valid device.

\subsection{Practicality}

The practicality test for Maritime English in the navigation function with the developed learning model is carried out through two types of assessment, namely: (1) theoretical assessment and (2) empirical assessment. Based on statistical analysis and the average of the three components in which there are aspects that are observed, it is known that based on the category table of the model implementation is declared entirely implemented. The whole category is implemented at the same time states that Maritime English in the navigation function is a practical learning.

\subsection{Effectiveness}

Based on the analysis of student officers' learning outcomes, it was found that the mean value obtained by student officers who obtained a learning result score greater than 70 was greater than the minimum requirement to state that the learning outcomes achieved classical completeness. This analysis also proves that based on the learning outcomes in four different scenarios, it is stated as effective learning. In the large Indonesian dictionary (1994), it is stated that effective means that there is an effect (effect, influence, impression) that can bring results and be effective. The success of this learning is in line with Mulyasa's (2004) statement that effectiveness can be defined as how an organization manages to obtain and utilize resources in an effort to realize its operational objectives.

\section{Conclusion And Suggestion}

\subsection{Conclusion}

Maritime English learning in the navigation function with the model developed in the seafarer education program is still carried out conventionally. Learning is carried out in classrooms or laboratories through lectures and exercises where the teacher becomes the center of information (Teacher Centered Learning) so that learning outcomes are not optimal. For this reason, Maritime English Learning is needed in the navigation function with the developed model.

All components in the assessment of the feasibility of the model are components that can be practically implemented. Maritime English Learning in the navigation function with a developed model is proven to be able to help student officers to achieve completeness of learning outcomes, namely the value of learning outcomes greater than 70 is as much as $88.4 \%$ of student officers.

\subsection{Suggestion}

Socializing Maritime English Learning in the navigation function with a model developed to all Maritime English teachers in shipping education.

\section{References}

[1] Aziz, A., \& Saihu, S. (2019). Interpretasi Humanistik Kebahasaan: Upaya Kontekstualisasi Kaidah Bahasa Arab. Arabiyatuna: Jurnal Bahasa Arab, 3(2), 299214 
[2] Borg, W. R., Gall, M.D. 2003. Education Research: An Introduction (7 $7^{\text {th }}$ Edition). Boston: Perason Education.

[3] Chappell, C. (2003). Changing pedagogy: Contemporary vocational learning. OVAL Research Working Paper 03-12. The Australian Centre for Organisational,

[4] Ghozali, I., 2002. Statistik Non Prametrik Teori dan Aplikasi dengan Program SPSS. Semaarang: Badan Penerbit Undip.

[5] Karli, dan Margaretha. (2002). Implementasi Kurikulum Berbasis Kompetensi. Bandung: FIP UPI.

[6] Mulyasa, E. 2004. Implementasi Kurikulum 2004. Bandung: Remaja Rosdakarya.

[7] Thomas, Neil (ed.), 2004. The John Adair Handbook of Management and Leadership, London: Thorogood.

[8] Vocational, and Adult Learning (OVAL), University of Technology, Sydney. Santrock, J. W. 2008. Psikologi Pendidikan edisi kedua. Jakarta : Kencana 